OPEN ACCESS

Edited by:

Luisella Verotta

University of Milan, Italy

Reviewed by:

Mohamed E. Abd El-Hack,

Zagazig University, Egypt

Emiliano Lasagna,

University of Perugia, Italy

Vito Laudadio,

University of Bari Aldo Moro, Italy

${ }^{*}$ Correspondence:

Marcella Massimini

marcella@nilitaly.com

Mariangela Pucci mpucci@unite.it

Specialty section:

This article was submitted to Animal Nutrition and Metabolism,

a section of the journal

Frontiers in Veterinary Science

Received: 14 September 2020

Accepted: 02 February 2021

Published: 05 March 2021

Citation:

Massimini M, Dalle Vedove $E_{\text {, }}$

Bachetti B, Di Pierro F, Ribecco C,

D'Addario C and Pucci M (2021)

Polyphenols and Cannabidiol

Modulate Transcriptional Regulation of Th1/Th2 Inflammatory Genes Related

to Canine Atopic Dermatitis.

Front. Vet. Sci. 8:606197.

doi: 10.3389/fvets.2021.606197

\section{Polyphenols and Cannabidiol} Modulate Transcriptional Regulation of Th1/Th2 Inflammatory Genes Related to Canine Atopic Dermatitis

\author{
Marcella Massimini ${ }^{1 *}$, Elena Dalle Vedove ${ }^{1}$, Benedetta Bachetti ${ }^{1}$, Francesco Di Pierro ${ }^{2}$, \\ Cataldo Ribecco ${ }^{1}$, Claudio D'Addario ${ }^{3}$ and Mariangela Pucci ${ }^{3 *}$ \\ ${ }^{1}$ R\&D Division, C.I.A.M. Srl, Ascoli, Italy, ${ }^{2}$ Velleja Research, Milan, Italy, ${ }^{3}$ Faculty of Bioscience and Technology for Food, \\ Agriculture and Environment, University of Teramo, Teramo, Italy
}

Canine atopic dermatitis (AD) is a multifactorial allergic disease associated with immune and abnormal skin barrier dysfunction and it is one of the primary causes of pruritus. Using a novel in vitro model of $A D$, here we tried to revert the alteration of transcriptional regulation of $A D$ canine key genes testing a nutraceutical mixture containing flavonoids, stilbene, and cannabinoids, which are already well-known for their applications within dermatology diseases. The nutraceutical mixture induced in inflamed cells a significant downregulation $(p<0.05)$ of the gene expression of $c c / 2, c c / 17$, and $t s / p$ in keratinocytes and of $c c / 2$, cc/17, and i/31ra in monocytes. Consistent with the observed alterations of ts/p, ccl2, ccl17, and il31ra messenger RNA (mRNA) levels, a significant increase $(p<0.05)$ of DNA methylation at specific CpG sites on the gene regulatory regions was found. These results lay the foundation for the use of these natural bioactives in veterinary medicine and provide a model for deeper understanding of their mechanisms of action, with potential translation to human research.

Keywords: epigenetic, polyphenols, phytocannabinoids, skin inflammation, veterinary research

\section{INTRODUCTION}

In veterinary dermatology practice, canine atopic dermatitis $(\mathrm{AD})$ is a multifactorial allergic disease that affects up to $27 \%$ of dogs; it is associated with immune and abnormal skin barrier dysfunction and it is one of the primary causes of pruritus (1). Many pharmacological options for its treatment already exist; however, due to elevated costs, side effects, and/or a long lag phase, treatments based on natural compounds are constantly being developed (2). In fact, due to their low toxicity and high efficacy, nutraceuticals are helpful for AD prevention and treatment (3).

Nutrigenomic studies in humans and animal models have clearly shown that nutraceuticals can influence signaling processes, cell apoptosis, metabolism, immune regulation, and modulate gene expression through epigenetic control $(4,5)$. Taking into account epigenetic modulations within $\mathrm{AD}$ and considering the importance of environment in disease progression, food supplements can delay the onset and improve the prognosis of the disease, giving support when anti-inflammatory feedback mechanisms fail to switch off, thereby avoiding an inflammatory over-response (6).

Atopic dermatitis treatment represents a challenge also in human medicine, given the high incidence and the substantial psychosocial burden involved; for these reasons, many studies are focused on characterizing the disease pathomechanisms in our and other species to find an optimal 
preclinical model for drug development (7). Transcriptomic analysis was performed for dogs in both skin biopsies from spontaneously occurring $\mathrm{AD}$ and from lesions induced by epicutaneous allergen challenge in Dermatophagoides farinae house dust mite-sensitized subjects (8-10). AD-related hypersensitivity is originally considered to be a Th2-polarized lymphocyte response, especially in the clinical acute phase of the disease; a large number of Th2 genes are upregulated in canine $\mathrm{AD}$ models, especially in those induced by house dust mites (11). It is known, to date, that, $\mathrm{AD}$ is often associated with multiple lymphocyte phenotypes characterized by the production of a complex variety of cytokines, including both Th1 and Th2 response mediators $(7,10)$. Increased mRNA levels of interleukin (IL)-4 and other Th2-related interleukins, such as IL-13 and IL-31, were seen in non-lesional and lesional atopic dogs (10), but recent ex vivo studies showed an high presence of interferon gamma (IFN- $\gamma$ ), the principal mediator of the Th1 response, in whole blood samples and skin biopsies from atopic dogs (12-14).

On the basis of the abovementioned mechanisms, advanced in vitro models were developed to enhance preclinical study for drug discovery, with the aim of decreasing in vivo tests (15). Our purpose was to test the effects of a nutraceutical mixture in a canine AD in vitro model, which takes into account the Th1/Th2 inflammation. Keratinocytes and monocytes were chosen for their significant involvement in $\mathrm{AD}$ progression $(16,17)$. In particular, the efficacy of the mixture was evaluated in terms of its ability to modulate the transcriptional regulation of the Th1/Th2-related genes, known to lead to a massive migration and maturation of blood leukocytes at the site of injury and to an increase of itch stimulus in $\mathrm{AD}(10,16)$.

The active principles included in the mixture are two polyphenols, flavone luteolin and stilbene piceatannol, and cannabidiol. They were selected for their already known involvement in reducing skin inflammation and allergic diseases $(18,19)$.

\section{MATERIALS AND METHODS}

\section{Materials}

Chemicals were of the purest analytical grade. IFN- $\gamma$ (781CG) and IL-13 (5894-CL) were purchased from R\&D System (Minneapolis, MN, USA), and IL-4 (754-CL) and IL-31 (59591) from Novus Biologicals (Centennial, CO, USA). Luteolin (sc203119A) was from Santa Cruz Biotechnology (Dallas, TX, USA), while piceatannol (S3026) and cannabidiol (C6395) were from Selleckchem (Houston, TX, USA) and Sigma-Aldrich (St. Louis, $\mathrm{MO}, \mathrm{USA})$, respectively.

\section{Cell Culture and Inflammatory Stimulation}

Canine monocyte-macrophage, DH82 (ATCC, Manassas, VA, USA) and canine epidermal keratinocyte progenitor (CPEK; CELLnTEC, Bern, Switzerland) cell lines were grown at $37^{\circ} \mathrm{C}$ in humidified 5\% $\mathrm{CO}_{2}$ atmosphere, in accordance with the manufacturer's recommended protocols. The DH82 cell line was seeded in complete growth medium containing Eagle's minimum essential medium (EMEM), 15\% fetal bovine serum, and 1\% penicillin/streptomycin; CPEK cells were seeded in complete epidermal keratinocyte medium (CELLnTEC, Bern, Switzerland) supplemented with $1 \%$ penicillin/streptomycin. At the optimal culture conditions and considering each cell line doubling time, $5 \times 10^{5}$ DH82 cells and $2.5 \times 10^{5}$ CPEK cells were seeded onto 60-mm Petri dishes; after $24 \mathrm{~h}$, cells were prestimulated with the Th1 cytokine IFN- $\gamma(5 \mathrm{ng} / \mathrm{ml})$ for $48 \mathrm{~h}$, then subjected to the inflammatory stimulation ("inflamed") with a Th2 interleukin mixture composed of IL-4 (50 ng/ml), IL-13 (50 ng/ml), and IL$31(50 \mathrm{ng} / \mathrm{ml})$ for $4 \mathrm{~h}$ and $8 \mathrm{~h}$. Inflammatory stimuli and dosage have been chosen from the literature with the aim to upregulate canine AD marker genes $(16,17,20,21)$.

\section{Nutraceutical Dosage Information and Effects on Cell Viability}

Inflamed cells were treated with the nutraceutical mixture containing luteolin, piceatannol, and cannabidiol at doses established through the literature and MTT assay results (22-24). The effects of the individual mixture components on the skin inflammation markers were already known in the literature so their synergic ability has been evaluated here (25-27). Piceatannol [dissolved in dimethyl sulfoxide (DMSO)] and luteolin and cannabidiol (dissolved in methanol) were added directly to the culture medium at the following concentrations (Mix 1: cannabidiol $10 \mu \mathrm{M}$, luteolin $10 \mu \mathrm{M}$, and piceatannol $10 \mu \mathrm{M}$; Mix 2: 10:25:25; Mix 3: 10:50:50; and Mix 4: 10:100:100 $\mu \mathrm{M}$ ) for $4 \mathrm{~h}$ and $8 \mathrm{~h}$. The culture medium containing vehicles alone was added to controls under the same conditions.

To determine the mixtures effect on the cell proliferation, $7.5 \times 10^{2}$ cells/well were seeded onto 96-well plates. At the beginning of the experiment, the complete growth medium was replaced with fresh medium containing the nutraceutical mixture or vehicles. After $4 \mathrm{~h}$ and $8 \mathrm{~h}$ of incubation, the supernatants were replaced with $0.1 \mathrm{ml}$ of the fresh medium without phenol red, containing $0.5 \mathrm{mg} / \mathrm{ml}$ of MTT; the plates were then returned to the incubator for $4 \mathrm{~h}$ and were gently shaken occasionally. Crystals of formazan (the MTT metabolic product) were solubilized by $0.1 \mathrm{ml}$ ethanol/DMSO 1:1 lysis buffer and spectrophotometrically quantified at a wavelength of $570 \mathrm{~nm}$ with the reference at a wavelength of $695 \mathrm{~nm}$. The differences in the cell growth were measured as a percentage of the growth rates of treated cells compared to untreated cultures.

\section{Gene Expression}

Total RNA was extracted from $\simeq 1 \times 10^{6}$ cells using the All Prep DNA/RNA Mini Kit (QIAGEN, Hilden, Germany) following the manufacturer's recommended protocol. Starting with $1 \mu \mathrm{g}$ of RNA templates, first strand complementary DNA (cDNA) was synthesized using the RevertAid H Minus First Strand cDNA Synthesis Kit (Thermo Fisher Scientific, Waltham, MA, USA). The relative abundance of the canine AD marker genes was evaluated by real-time PCR using the SensiFAST SYBR Lo-ROX kit (Bioline, London, UK) on a 7500 Fast Real-Time PCR System (Thermo Fisher Scientific, Waltham, MA, USA) in both cell lines. The primers used for the amplification are reported in Table 1, and all of the data were normalized to the endogenous reference gene $\beta$-actin. 
TABLE 1 | Primer sequences used to analyze mRNA expression levels of canine genes.

\begin{tabular}{|c|c|c|}
\hline Gene & Forward $\left(5^{\prime} \rightarrow 3^{\prime}\right)$ & Reverse $\left(5^{\prime} \rightarrow 3^{\prime}\right)$ \\
\hline$i l 4 r$ & GAAAGGATGGTGGGATCAGA & CAAGCTCCTGCCCTGTCTAC \\
\hline il31ra & $\begin{array}{l}\text { ATGGATGCTCCTTCTACTCTGT } \\
\text { AAACT }\end{array}$ & CAGGAAATGTTCTCAGGCTTAGC \\
\hline i/31 & СTCTCCCACACAGGACCATC & TGGGAGGACAGCAAGGTाC \\
\hline ccl2 & CCTGCTGCTATACACTCA & GCTTCTITGGGACACTTG \\
\hline cc/5 & CAGTCGTCTITGTCACCCGA & TGTACTCCCGCACCCATITC \\
\hline cc/17 & GCCATCGTGTITGTAACT & СTCCCTTCCAGGTTCTITGT \\
\hline$t s / p$ & AGTACACGGGGTGGCTGA & GTCATIACCAAGCCCTGGA \\
\hline ctss & AAAGCGAGCTGCCACATGT & TTAAGGCATCTTCACTGCCAAA \\
\hline$\beta$-actin & ТTCCGCTGCCCAGAGGCTCT & GCTCAGGGGGTGCGATGATCTTG \\
\hline
\end{tabular}

\section{DNA Methylation Analysis by Pyrosequencing}

The DNA methylation levels of the specific CpG sites were determined using bisulfite-converted DNA from DH82 and CPEK cells by pyrosequencing. The genomic DNA was simultaneously purified with RNA as mentioned above, and DNA $(1 \mu \mathrm{g})$ was subjected to bisulfite modification using the EZ DNA Methylation Kit (Zymo Research, Irvine, CA, USA).

The bisulfite-treated DNA was amplified using the PyroMark PCR Kit (QIAGEN, Hilden, Germany) according to the protocol of the manufacturer. The PCR conditions were as follows: $95^{\circ} \mathrm{C}$ for $15 \mathrm{~min}$, followed by $45 \mathrm{cycles}$ of $94^{\circ} \mathrm{C}$ for $30 \mathrm{~s}, 56^{\circ} \mathrm{C}$ for $30 \mathrm{~s}$, $72^{\circ} \mathrm{C}$ for $30 \mathrm{~s}$, and finally, $72^{\circ} \mathrm{C}$ for $10 \mathrm{~min}$. After product quality verification by $1.8 \%$ agarose electrophoresis, the pyrosequencing methylation analysis was conducted using the PyroMark Q24 (QIAGEN, Hilden, Germany). The level of methylation was analyzed using PyroMark Q24 software (QIAGEN, Hilden, Germany), which calculates the methylation percentage using the following formula: methylated cytosine/methylated cytosine + unmethylated cytosine. Quantitative methylation results were considered, both as a percentage of single CpG sites and as an average of the methylation percentage of all the investigated $\mathrm{CpG}$ sites. A schematic representation of a CpG island and the details of the pyrosequencing assay are given in Figure $\mathbf{1}$ and Table 2, respectively.

\section{Statistical Analysis}

Data were expressed as the mean \pm SEM for each group and were analyzed using the GraphPad Prism version 8.0.0 (GraphPad Software, San Diego, CA, USA). Data from the MTT assay were statistically evaluated by the one-way ANOVA followed by the Bonferroni's multiple comparison test for further examination of group differences $(p<0.05)$.

The gene expression was analyzed by three-way ANOVA using the factors "inflammation," "nutraceuticals treatment," and "time" followed by the Bonferroni's post-hoc test to follow up on significant interactions or main effects $(p<0.05)$ from the factorial ANOVA. The effects of the nutraceutical treatment on inflamed cells were evaluated using the two-way ANOVA, and the one-way ANOVA was used in cases of no interaction between factors (nutraceuticals and time). The statistical differences with respect to average DNA methylation changes at gene promoters were analyzed by multiple $t$-tests $(p<0.05)$.

\section{RESULTS}

\section{Effects of Inflammation on AD Markers Gene Expression}

The effects evoked by the inflammatory stimulation on canine DH82 and CPEK cells on the expression of selected genes were assessed by real-time PCR, and the results are shown in Table 3 (CPEK cell line; "keratinocytes") and 4 (DH82 cell line; "monocytes"). Selected genes derived from a previous screening aimed to sort markers of inflammation in stimulated cells (the data regarding model time course are not shown). Three-way ANOVA showed, among the selected genes, an increase in mRNA levels in inflamed cells (Inflamed: yes; Mix: no) with respect to the control (Inflamed: no; Mix: no). The Bonferroni's post-hoc test results are shown in Tables 3,4 .

\section{Effects of the Nutraceutical Mixture on Cell Viability}

The effects of different nutraceutical mixtures on cell viability were tested on CPEK and DH82 cells (Figure 2). Inflamed cells, previously stimulated as shown in section Materials and Methods, were exposed to different concentrations of cannabidiol, luteolin, and piceatannol (Mix 1: cannabidiol $10 \mu \mathrm{M}$, luteolin $10 \mu \mathrm{M}$, and piceatannol $10 \mu \mathrm{M}$; $\operatorname{Mix} 2$ : 10:25:25 $\mu \mathrm{M}$; Mix 3: 10:50:50 $\mu \mathrm{M}$, and Mix 4: 10:100:100 $\mu \mathrm{M}$ ) for $4 \mathrm{~h}$ and $8 \mathrm{~h}$. One-way ANOVA showed that the exposure to the nutraceutical mixtures induced a significant change in the percentage viability of CPEK cells $\left[F_{(9,20)}=30.45\right]$, and posthoc comparisons using the Bonferroni's test revealed a significant decrease in the groups treated for 4 and $8 \mathrm{~h}$ with Mix 4 with respect to control $(4 \mathrm{~h}=63.80 \pm 1.17, p<0.001 ; 8 \mathrm{~h}=45.04$ $\pm 5.81, p<0.001)$. Moreover, $8 \mathrm{~h}$ of exposure to Mix 2 induced a significant increase in cell viability $(127.96 \pm 3.95 ; p=0.0081)$ (Figure 2A).

The nutraceutical mixtures induced changes in DH82 cell viability $\left[F_{(9,20)}=22.58 ; p<0.001\right]$. The Bonferroni's comparison test revealed a decrease in cell viability with respect to control after Mix 4 treatment for 4 and $8 \mathrm{~h}(4 \mathrm{~h}=76.87 \pm 2.45$, $p<0.001 ; 8 \mathrm{~h}=68.22 \pm 1.16, p<0.001)$. Moreover, a significant decrease in the percentage viability was observed in the DH82 cells treated with Mix 3 for $8 \mathrm{~h}(79.59 \pm 2.37 ; p=0.0029)$ (Figure 2B). Due to its ability to enhance CPEK viability without provoking cell death in the DH82 cell line, Mix 2 was chosen for all the subsequent experiments.

\section{Effects of the Nutraceutical Mixture on Transcriptional Regulation in Inflamed Cells}

The consequences of the nutraceutical mixture (Mix 2) treatment after 4 and $8 \mathrm{~h}$ on the inflamed cells are shown in Figure 3 and Table 3 (CPEK) and Figure 4 and Table 4 (DH82). 

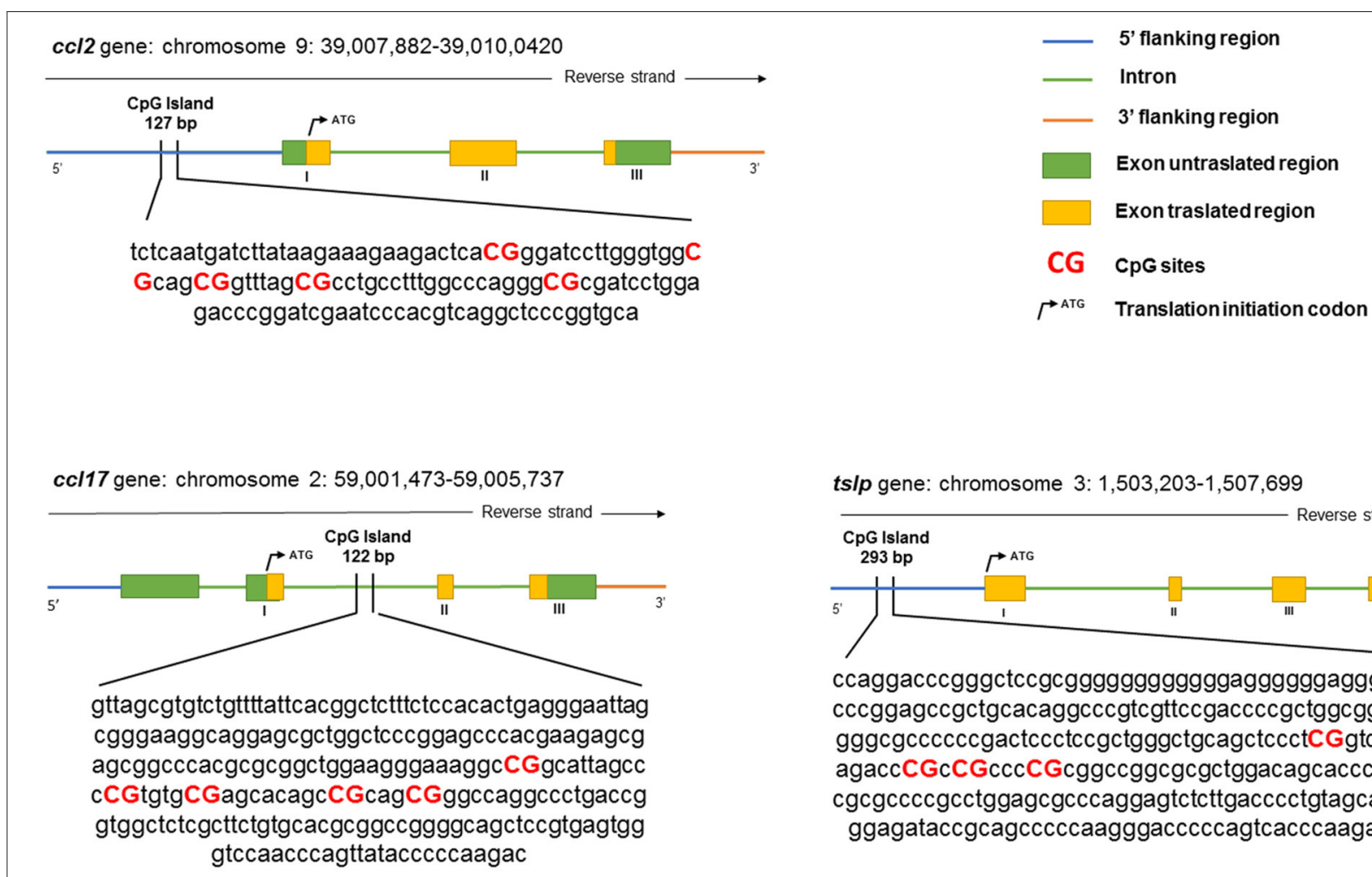

ccl17 gene: chromosome 2: 59,001,473-59,005,737

tslp gene: chromosome 3: 1,503,203-1,507,699

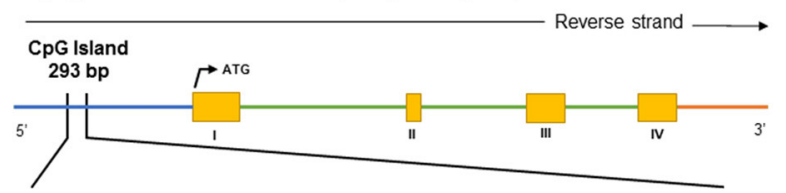

ccaggacccgggctccgcgggggggggggggaggggggagggtggacat cccggagccgctgcacaggcccgtcgttccgacccogctggcgggettctcc gggcgcccccoactccctccgctgggctgcagctccctCGgtcCGCGt agaccCGcCGcccCGcggccggcgcgctggacagcaccctcccccg cgcgccccgcctggagcgcccaggagtctcttgaccctgtagcacgtgcta ggagataccgcagccccaagggacccccagtcacccaagagcagg

il31ra gene: Chromosome 2: 43,144,071-43,192,293

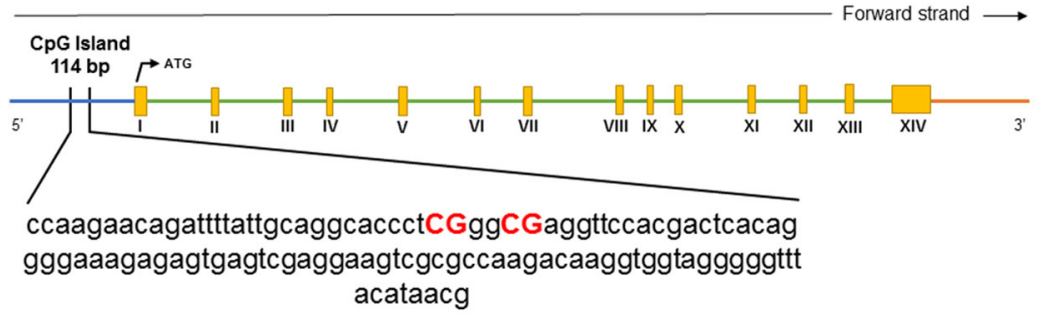

FIGURE 1 | The schematic representation of the analyzed canine genes.

The statistical analysis using two-way ANOVA showed that ccl2 mRNA levels in inflamed CPEK cells were affected by time $\left[F_{(1,8)}=19.32 ; p=0.0023\right]$ and Mix 2 treatment $\left[F_{(1,8)}=234.0\right.$; $p<0.001]$, with a significant interaction between these two factors $\left[F_{(1,8)}=66.62 ; p<0.001\right]$. The Bonferroni's post-hoc test results are shown in Figure 3A.

An alteration of ccll7 expression was observed in CPEK cells inflamed and exposed to the Mix 2 for 4 and $8 \mathrm{~h}$ (Figure 3B). The two-way ANOVA showed that mRNA levels were affected by the Mix 2 treatment $\left[F_{(1,8)}=50.79 ; p<0.001\right]$ but not by time $\left[F_{(1,8)}=1.03 ; p=0.3403\right]$, without an interaction between the two factors $\left[F_{(1,8)}=0.11 ; p=0.7502\right]$. The one-way ANOVA further showed that the $c c l 17$ mRNA levels in CPEK cells were significantly affected by treatment
$\left[F_{(3,8)}=17.31 ; p<0.001\right]$, and post-hoc comparisons are indicated in Figure 3B.

The statistical analysis using the two-way ANOVA showed that $t$ slp expression in CPEK cells was also affected by treatment $\left[F_{(1,8)}=26.19 ; p<0.001\right]$ but not by time $\left[F_{(1,8)}=2.16\right.$; $p=0.18]$, without a significant interaction between these two factors $\left[F_{(1,8)}=2.37 ; p=0.16\right]$. The one-way ANOVA further showed that the $t s l p$ gene expression was affected by treatment $\left[F_{(3,8)}=10.24 ; p=0.004\right]$ (Figure 3C). The Bonferroni's post-hoc test results are shown in Figure 3C.

The two-way ANOVA showed that the il4r mRNA levels in CPEK cells were not affected by the Mix 2 treatment $\left[F_{(1,8)}=0.08 ; p=0.80\right]$ but were affected by time $\left[F_{(1,8)}=76.64\right.$; $p<0.001$ ], without an interaction between the two factors 
$\left[F_{(1,8)}=0.15 ; p=0.71\right]$. As mentioned earlier, time affected the iltr gene expression $\left[F_{(3,8)}=25.62 ; p<0.001\right]$, and post-hoc comparisons are indicated in Figure 3D.

In inflamed monocytes, the $c c l 2$ gene expression was affected by the Mix 2 treatment $\left[F_{(1,8)}=18.80 ; p=0.002\right]$ but not by time $\left[F_{(1,8)}=3.51 ; p=0.10\right]$, without an interaction between the factors $\left[F_{(1,8)}=2.12 ; p=0.18\right]$. The one-way ANOVA further showed that the $c c l 2$ mRNA levels were affected by treatment $\left[F_{(3,8)}=8.146 ; p=0.0082\right]$. The Bonferroni's post-hoc test results are shown in Figure 4A.

The gene expression of ccl17 in DH82 cells was affected by time $\left[F_{(1,8)}=14.04 ; p=0.006\right]$ and Mix 2 treatment

TABLE 2 | Primer sequences used to analyze DNA methylation levels of canine genes.

\begin{tabular}{|c|c|}
\hline Gene & Forward $\left(5^{\prime} \rightarrow 3^{\prime}\right)$ \\
\hline ccl2 & GGGAAGTITGTGTATITATAGGTATTG \\
\hline cc/17 & AGGGAATTAGAGGGAAGGTAGGA \\
\hline il31ra & GAGGGTTAAGAATAGATITATTGTAGGT \\
\hline$t s / p$ & TITAGTAAGTGTTATAGGGGTTAAGAGAT \\
\hline Gene & Reverse biotinylated $\left(5^{\prime} \rightarrow 3^{\prime}\right)$ \\
\hline ccl2 & AACAAAAAAAAAAACAAACTCCATAC \\
\hline$c c / 17$ & TAAAAACCCCCAACAACCTCC \\
\hline I/31ra & AAACCCCCTACCACCTTATCTT \\
\hline$t s / p$ & АСТСССТССССТАААСТАСАAС \\
\hline Gene & Sequencing $\left(5^{\prime} \rightarrow 3^{\prime}\right)$ \\
\hline ccl2 & AATGATITATAAGAAAGAAGATT \\
\hline$c c / 17$ & GGTTGGAAGGGAAAG \\
\hline il31ra & AATAGATITTATTGTAGGTATT \\
\hline$t s / p$ & GGGGTTAAGAGATाПTG \\
\hline
\end{tabular}

$\left[F_{(1,8)}=44.48 ; p<0.001\right]$ with a positive interaction between factors $\left[F_{(1,8)}=12.87 ; p=0.007\right]$. The post-hoc comparison test results are reported in Figure 4B.

The expression of tslp in DH82 cells was dependent on time $\left[F_{(1,8)}=29.59 ; p<0.001\right]$ but was not affected by the Mix 2 treatment $\left[F_{(1,8)}=0.004 ; p=0.95\right]$, with no interaction between factors $\left[F_{(1,8)}=0.004 ; p=0.95\right]$. The one-way ANOVA further showed that the $t$ slp gene expression was affected by time $\left[F_{(3,8)}=9.86 ; p=0.005\right]$ (Figure 4C). The Bonferroni's post-hoc test results are shown in Figure 4C.

Finally, the il31ra expression in DH82 cells was affected by treatment $\left[F_{(1,8)}=18.68 ; p=0.002\right]$ but not by time $\left[F_{(1,8)}=0.4520 ; p=0.5203\right]$, with no interaction between factors $\left[F_{(1,8)}=5.07 ; p=0.05\right]$. The one-way ANOVA further showed that the il31ra gene expression was affected by the treatment $\left[F_{(3,8)}=8.07 ; p=0.008\right]$, and the post-hoc comparisons are indicated in Figure 4D.

\section{Nutraceutical Effects on DNA Methylation}

In order to evaluate whether the epigenetic mechanisms could account for the gene expression changes, we analyzed the DNA methylation at specific promoter regions. The DNA methylation analysis for each $\mathrm{CpG}$ site as well as the average values for inflamed cells is shown in Tables 5, 6 .

In the inflamed CPEK cells exposed to the Mix 2 for 4 and $8 \mathrm{~h}$, we failed to observe any overall alteration in the percentage of DNA methylation at $c c l 2, c c l 17$, and $t s l p$ gene promoters with respect to the $\mathrm{CpG}$ sites analyzed. Multiple $t$-test comparisons showed, in inflamed cells exposed for $4 \mathrm{~h}$ to Mix 2, a significant decrease in the percentage of DNA methylation at the third CpG site in the promoter region of $c c l 17(75.22 \pm 2.35$ Yes Mix vs. $81.44 \pm 1.87$ No Mix; $p=0.02$ ) (Figure 5A) and an increase in the first CpG site of $t$ slp evaluated $(96.43 \pm 0.44$ Yes Mix vs. 95.06 \pm 0.43 No Mix; $p=0.02$ ) (Figure 5B).

In the inflamed DH82 cells, the $c c l 2$ gene promoter showed a substantial methylation increase in $\mathrm{CpG}$ site 2 for cells

TABLE 3 | The effects of the nutraceutical treatment on the relative expression (fold change) of canine AD marker genes on CPEK keratinocytes.

CPEK

\begin{tabular}{|c|c|c|c|c|c|c|c|c|}
\hline \multirow{3}{*}{$\begin{array}{l}\text { Time } \\
\text { Inflamed } \\
\text { Mix }\end{array}$} & \multicolumn{4}{|c|}{$4 h$} & \multicolumn{4}{|c|}{$8 h$} \\
\hline & \multicolumn{2}{|c|}{ No } & \multicolumn{2}{|c|}{ Yes } & \multicolumn{2}{|c|}{ No } & \multicolumn{2}{|c|}{ Yes } \\
\hline & No & Yes & No & Yes & No & Yes & No & Yes \\
\hline ccl2 & $1.05 \pm 0.16$ & $1.39 \pm 0.39$ & $9.65 \pm 0.34^{a}$ & $5.74 \pm 0.77^{a, b, c}$ & $0.62 \pm 0.04$ & $0.74 \pm 0.31$ & $16.53 \pm 1.44^{\mathrm{a}, \mathrm{b}, \mathrm{c}, \mathrm{e}}$ & $3.67 \pm 0.88^{a, d, e, f}$ \\
\hline cc/5 & $1.00 \pm 0.19$ & $1.10 \pm 0.07$ & $3.47 \pm 0.88^{a}$ & $4.20 \pm 1.42^{a, b}$ & $0.62 \pm 0$ & $1.21 \pm 0$ & $4.82 \pm 0.89^{a, b, e}$ & $2.68 \pm 0.4^{f}$ \\
\hline $\operatorname{ccl} 17$ & $1.03 \pm 0.16$ & $0.50 \pm 0.12$ & $1.77 \pm 0.2^{\mathrm{a}}$ & $0.56 \pm 0.03^{c}$ & $1.10 \pm 0.24$ & $0.51 \pm 0.01$ & $1.88 \pm 0.32^{\mathrm{a}, \mathrm{b}, \mathrm{e}}$ & $0.78 \pm 0.4^{f}$ \\
\hline$t s / p$ & $1.02 \pm 0.41$ & $0.30 \pm 0.11$ & $2.17 \pm 0.81^{a}$ & $0.48 \pm 0.23^{c}$ & $0.40 \pm 0.07$ & $0.27 \pm 0.05$ & $1.41 \pm 0.04^{b}$ & $0.50 \pm 0.24$ \\
\hline il31r & $1.02 \pm 0.22$ & $1.15 \pm 0.46$ & $1.73 \pm 0.1$ & $1.52 \pm 0.56$ & $1.00 \pm 0.02$ & $1.05 \pm 0.25$ & $4.74 \pm 0.46^{\mathrm{a}, \mathrm{b}, \mathrm{c}, \mathrm{e}}$ & $4.72 \pm 0.91^{\mathrm{a}, \mathrm{d}, \mathrm{e}}$ \\
\hline$i l 4 r$ & $1.00 \pm 0.07$ & $1.03 \pm 0.11$ & $2.36 \pm 0.14^{a}$ & $2.25 \pm 0.21^{a, b}$ & $0.29 \pm 0.02$ & $0.37 \pm 0.1$ & $0.93 \pm 0.22^{c}$ & $0.95 \pm 0.41^{d}$ \\
\hline ctss & $1.04 \pm 0.3$ & $1.03 \pm 0.2$ & $2.11 \pm 0.29$ & $2.00 \pm 0.48$ & $0.74 \pm 0.03$ & $0.88 \pm 0.35$ & $2.29 \pm 0.42^{b, e}$ & $1.87 \pm 0.86$ \\
\hline il31 & $1.07 \pm 0.27$ & $0.62 \pm 0.19$ & $0.91 \pm 0.1$ & $0.72 \pm 0.04$ & $0.70 \pm 0.03$ & $0.47 \pm 0.03$ & $1.11 \pm 0.43$ & $1.13 \pm 0.15$ \\
\hline
\end{tabular}

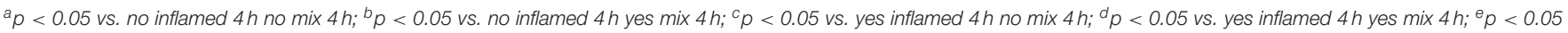
vs. no inflamed $8 h$ no mix $8 h ;{ }^{f} p<0.05$ vs. yes inflamed $8 h$ no mix $8 h$. 
TABLE 4 | The effects of the nutraceutical treatment on the relative expression (fold change) of canine AD marker genes on DH82 monocytes.

\begin{tabular}{|c|c|c|c|c|c|c|c|c|}
\hline \multicolumn{9}{|c|}{ DH82 } \\
\hline \multirow{2}{*}{$\frac{\frac{\text { Time }}{\text { Inflamed }}}{\text { Mix }}$} & \multicolumn{2}{|c|}{ No } & \multicolumn{2}{|c|}{ Yes } & \multicolumn{2}{|c|}{ No } & \multicolumn{2}{|c|}{ Yes } \\
\hline & No & Yes & No & Yes & No & Yes & No & Yes \\
\hline ccl2 & $1.01 \pm 0.21$ & $0.37 \pm 0.06$ & $3.52 \pm 0.61^{a}$ & $1.92 \pm 0.11^{\mathrm{b}, \mathrm{c}}$ & $1.17 \pm 0.16$ & $0.27 \pm 0.03$ & $2.60 \pm 0.71^{\mathrm{a}, \mathrm{b}, \mathrm{e}}$ & $1.80 \pm 0.12$ \\
\hline tslp & $1.03 \pm 0.25$ & $1.14 \pm 0.23$ & $3.30 \pm 0.64^{a}$ & $3.30 \pm 0.79^{a, b}$ & $0.94 \pm 0.28$ & $1.01 \pm 0.12$ & $1.69 \pm 0.09^{c}$ & $1.65 \pm 0.11^{d}$ \\
\hline il31r & $0.97 \pm 0.32$ & $1.69 \pm 0.24$ & $10.45 \pm 0.52^{a}$ & $4.90 \pm 1.72^{\mathrm{a}, \mathrm{b}, \mathrm{c}}$ & $1.04 \pm 0.13$ & $0.44 \pm 0.1$ & $4.41 \pm 1.14^{\mathrm{a}, \mathrm{b}, \mathrm{c}, \mathrm{e}}$ & $3.45 \pm 0.56^{\mathrm{a}, \mathrm{e}}$ \\
\hline ctss & $1.02 \pm 0.2$ & $1.20 \pm 0.34$ & $3.58 \pm 0.53^{a}$ & $3.42 \pm 0.43^{\mathrm{a}, \mathrm{b}}$ & $0.98 \pm 0.14$ & $1.29 \pm 0.54$ & $3.21 \pm 1.02^{\mathrm{a}, \mathrm{b}, \mathrm{e}}$ & $3.38 \pm 0.84^{a, e}$ \\
\hline$i 4 r$ & $1.03 \pm 0.3$ & $1.20 \pm 0.72$ & $1.66 \pm 0.53$ & $1.43 \pm 0.19$ & $1.06 \pm 0.17$ & $1.13 \pm 0.59$ & $0.90 \pm 0.19$ & $1.02 \pm 0.17$ \\
\hline il31 & $1.03 \pm 0.11$ & $0.87 \pm 0.35$ & $1.22 \pm 0.1$ & $1.15 \pm 0.05$ & $1.19 \pm 0.16$ & $1.36 \pm 0.18$ & $1.59 \pm 0.05^{\mathrm{a}, \mathrm{b}}$ & $1.36 \pm 0.07$ \\
\hline
\end{tabular}

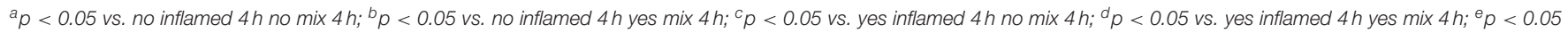
vs. no inflamed $8 \mathrm{~h}$ no mix $8 h{ }^{f} p<0.05$ vs. yes inflamed $8 \mathrm{~h}$ no mix $8 \mathrm{~h}$.

A

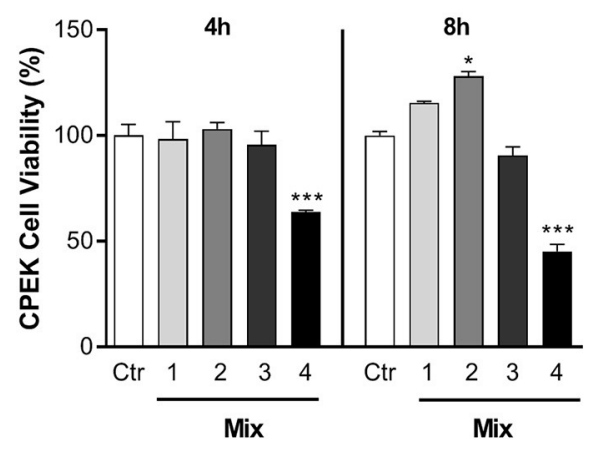

B

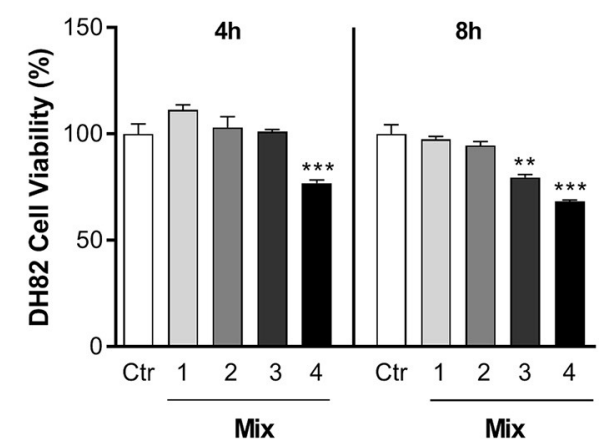

FIGURE 2 | The effects of nutraceutical mixtures on the viability of inflamed cells. Inflamed (A) CPEK and (B) DH82 cells were treated with nutraceutical mixtures containing an increasing ratio of luteolin and piceatannol to cannabidiol for 4 and $8 \mathrm{~h}$. Cell viability is expressed as the percentage of untreated cells (vehicle alone $=100 \%$ cell viability). The bar graphs show the mean + SEM of three independent experiments performed in triplicate. The statistically significant differences between experimental conditions and untreated control cells are shown by asterisks $\left({ }^{\star} p<0.01,{ }^{* *} p<0.01,{ }^{* \star *} p<0.001\right)$.

treated for $4 \mathrm{~h}$ with respect to untreated cells (Yes Mix $91.46 \pm 1.19$, No Mix $79.52 \pm 6.16 ; p=0.03$ ) (Figure 6A). Moreover, an increase in the percentage of DNA methylation was observed in $\mathrm{CpG}$ site 6 in cells treated for $8 \mathrm{~h}$ (Yes Mix $84.39 \pm 3.86$ ) with respect to untreated cells (No Mix $73.88 \pm 4.11 ; p=0.03)$ and $4 \mathrm{~h}$ treated cells $(76.90 \pm 3.31$; $p=0.016$ ) (Figure 6B). A decrease in the percentage of methylation, after $8 \mathrm{~h}$ of Mix 2 exposure, was also observed in site 1 with respect to $4 \mathrm{~h}$ Mix 2-treated cells (77.43 \pm 1.06 Yes Mix $8 \mathrm{~h}$ vs. $87.95 \pm 1.80$ Yes Mix $4 \mathrm{~h} ; p<0.001)$ (Figure 6C). The nutraceutical mixture exposure induced a significant increase in the percentage of methylation in $c c l 17$ site 3 after $8 \mathrm{~h}$ (Yes Mix $84.17 \pm 0.97$ vs. No Mix $76.27 \pm 1.33$; $p=0.001$ ) (Figure 6D). A significant increase in the percentage of methylation in il31ra site 2 was observed after $4 \mathrm{~h}$ in the treated cells $(47.21 \pm 2.20$ vs. $43.07 \pm 1.29$ No Mix; $p=0.047)$ (Figure 6E).

Moreover, the significant differences between groups, considering also those not inflamed, were evaluated through the three-way ANOVA, and multiple $t$-test comparisons are shown in Supplementary Tables 1, 2.

\section{DISCUSSION}

The first goal of our study was to identify a set of inflammation markers in an in vitro model of canine $\mathrm{AD}$. Of relevance, the transcriptional regulation of many of these markers was modulated by the nutraceutical exposure. It is well-established that the regular use of dietary supplements, such as essential fatty acids (EFAs), polyphenols, probiotics, or vitamins, has benefits for atopic animals (28-32). Their mechanisms of action in canine $\mathrm{AD}$ are not completely elucidated but may involve binding of toll-like receptors and downregulation of the predominately Th2mediated allergic response $(3,33,34)$. The AD pharmacological treatments targeted the JAK/STAT pathway to prevent the downstream signaling of cytokines associated with the Th1/Th2 inflammatory response, an approach particularly supported by recent evidence which demonstrated the strong involvement of 

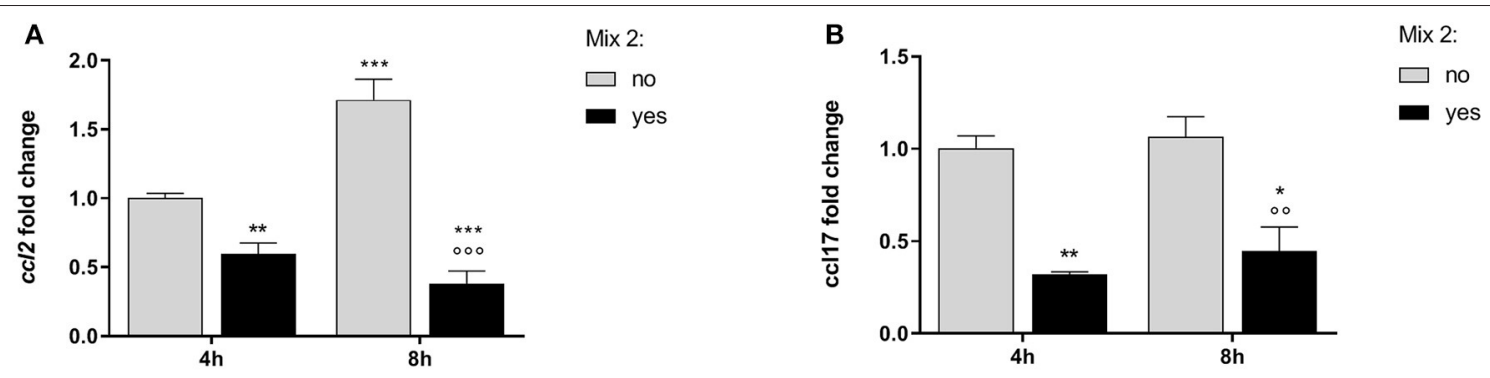

C

D
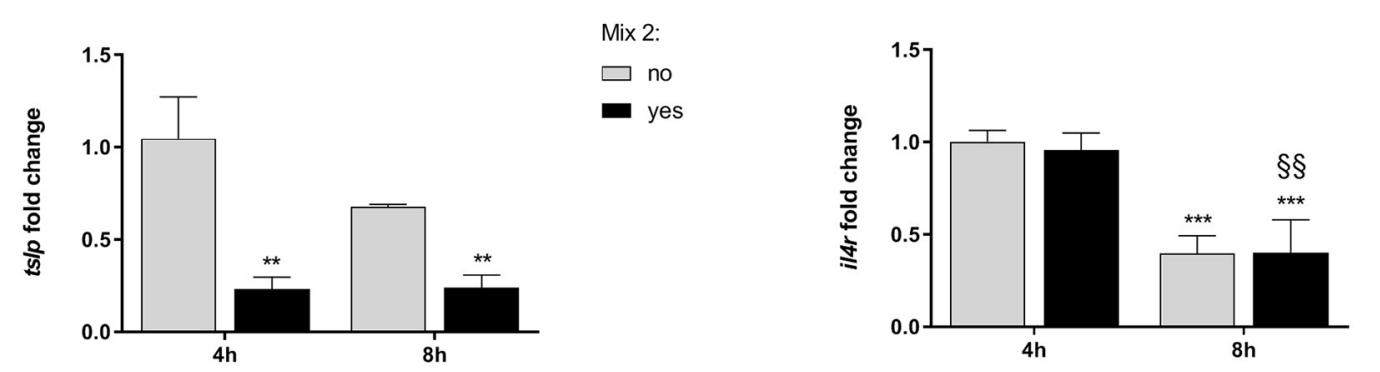

Mix 2:

$\square$ no

a yes

FIGURE 3 | The relative expression of canine atopic dermatitis (AD) marker genes after the nutraceutical mixture treatment in CPEK cells. Inflamed cells were treated (Mix yes) or not (Mix no) with the nutraceutical mixture (Mix 2) for 4 and $8 \mathrm{~h}$. The bar graphs show the mean + SEM of three independent experiments performed in triplicate. The gene expression of $c c / 2$ (A), ccl17 (B), ts/p (C), and $i / 4 r(\mathbf{D})$ was calculated using the delta-delta Ct $(\Delta \Delta \mathrm{Ct})$ method. The statistically significant differences between experimental conditions are reported as follows: ${ }^{\star} p<0.05,{ }^{\star *} p<0.01,{ }^{\star \star \star} p<0.001$ vs. no mix 4 h; $\$ \S p<0.01$, vs. yes mix 4 h; ${ }^{\circ 00} p<0.001$ vs. no mix $8 \mathrm{~h}$.
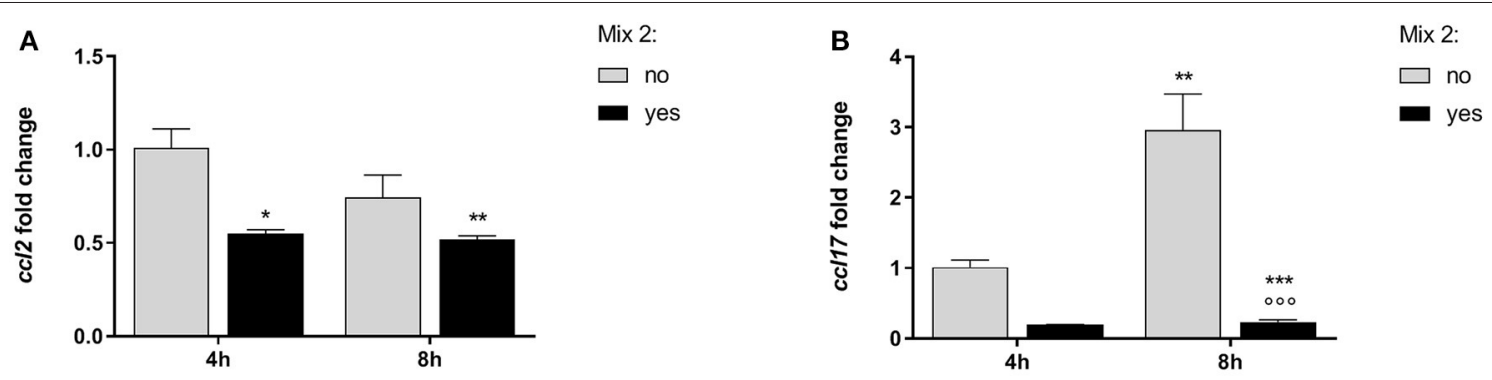

C

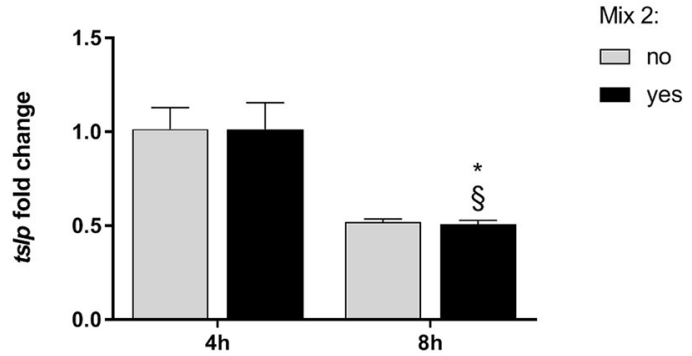

D

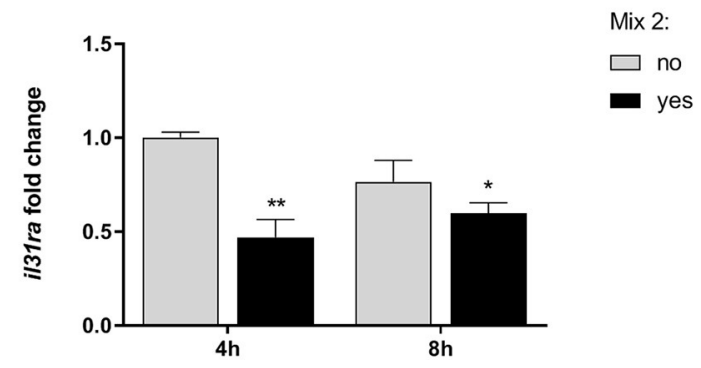

FIGURE 4 | The relative expression of canine AD marker genes after the nutraceutical mixture treatment in DH82 cells. Inflamed cells were treated (Mix yes) or not (Mix no) with the nutraceutical mixture (Mix 2) for 4 and $8 \mathrm{~h}$. The bar graphs show the mean + SEM of three independent experiments performed in triplicate. The gene expression of $c c / 2$ (A), ccl17 (B), ts/p (C), and il31ra (D) was calculated using the delta-delta Ct $(\Delta \Delta$ Ct) method. The statistically significant differences between experimental conditions are reported as follows: ${ }^{\star} p<0.05$, ${ }^{\star \star} p<0.01$, ${ }^{\star * \star} p<0.001$ vs. no mix 4 h; ${ }^{\S} p<0.05$ vs. yes mix 4 h. 
TABLE 5 | The DNA methylation (\%) changes at inflamed modulated gene promoters after the mixture treatment of inflamed CPEK cells.

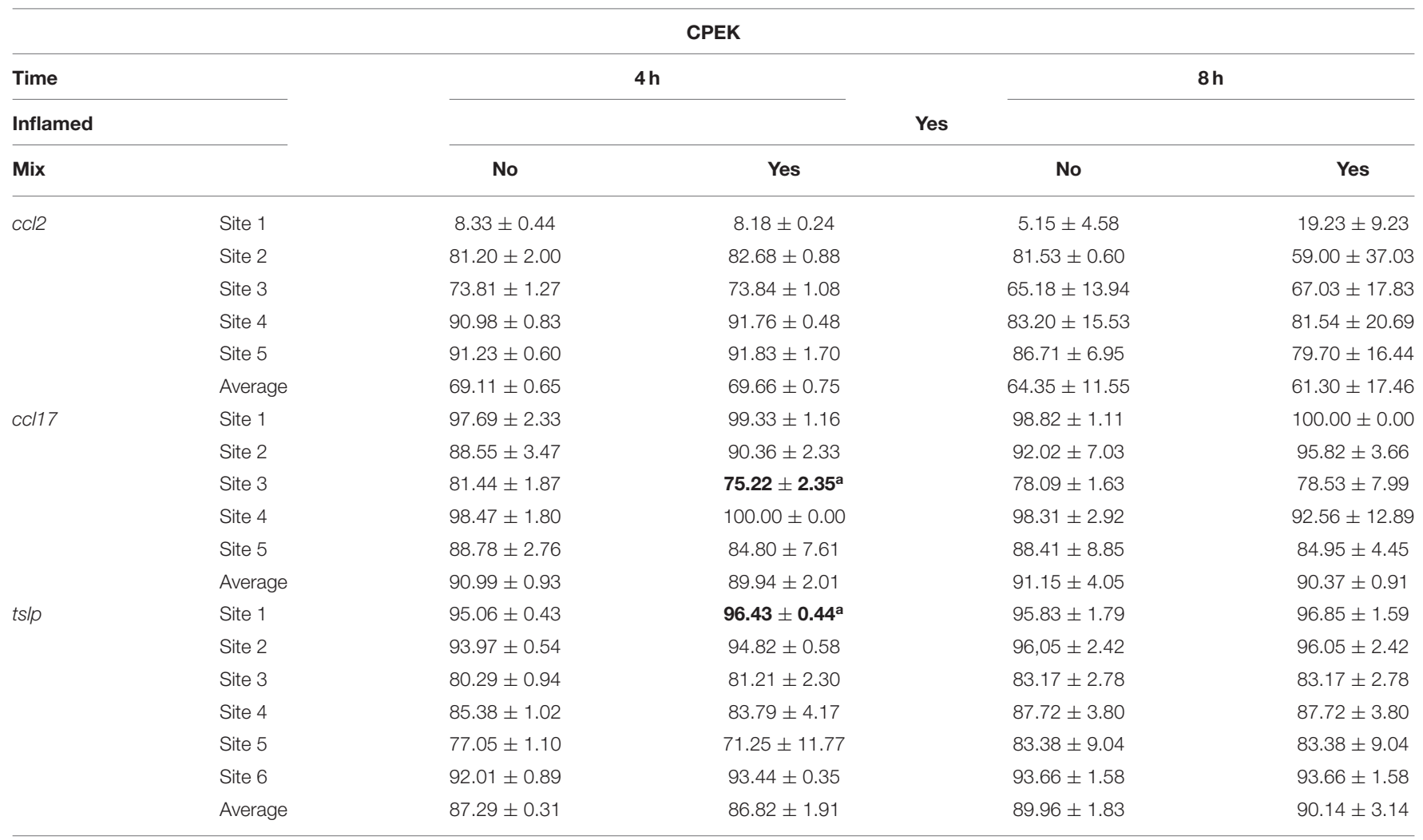

${ }^{a} p<0.05$ vs. yes inflamed $4 h$ no mix $4 h$.

TABLE 6 | The DNA methylation (\%) changes at inflamed modulated gene promoters after the mixture treatment of inflamed DH82 cells.

\begin{tabular}{|c|c|c|c|c|c|}
\hline \multicolumn{6}{|c|}{ DH82 } \\
\hline \multicolumn{2}{|c|}{ Inflamed } & \multicolumn{4}{|c|}{ Yes } \\
\hline Mix & & No & Yes & No & Yes \\
\hline \multirow[t]{5}{*}{ ccl2 } & Site 1 & $81.20 \pm 6.39$ & $87.95 \pm 1.80$ & $77.91 \pm 5.97$ & $77.43 \pm 1.06^{b}$ \\
\hline & Site 4 & $92.49 \pm 3.56$ & $97.06 \pm 0.85$ & $96.06 \pm 0.38$ & $96.34 \pm 0.39$ \\
\hline & Site 5 & $93.51 \pm 6.96$ & $95.62 \pm 1.52$ & $92.15 \pm 4.97$ & $94.60 \pm 1.71$ \\
\hline & Site 6 & $76.32 \pm 2.95$ & $76.90 \pm 3.31$ & $73.88 \pm 4.11$ & $84.39 \pm 3.86^{b, c}$ \\
\hline & Average & $85.54 \pm 3.69$ & $90.65 \pm 0.79$ & $86.29 \pm 3.30$ & $88.53 \pm 0.97$ \\
\hline \multirow[t]{3}{*}{ cc/17 } & Site 1 & $100.00 \pm 0.00$ & $99.38 \pm 0.88$ & $99.25 \pm 1.30$ & $100.00 \pm 0.00$ \\
\hline & Site 5 & $89.11 \pm 1.75$ & $89.12 \pm 2.19$ & $86.79 \pm 1.81$ & $89.60 \pm 1.54$ \\
\hline & Average & $93.34 \pm 2.94$ & $90.39 \pm 5.18$ & $88.71 \pm 2.05$ & $89.25 \pm 2,38$ \\
\hline \multirow[t]{3}{*}{ il31ra } & Site 1 & $44.88 \pm 1.34$ & $49.25 \pm 4.57$ & $50.30 \pm 3.27$ & $48.46 \pm 0.59$ \\
\hline & Site 2 & $43.07 \pm 1.29$ & $47.21 \pm 2.20^{\mathrm{a}}$ & $47.46 \pm 3.59$ & $45.49 \pm 1.92$ \\
\hline & Average & $43.98 \pm 0.86$ & $48.23 \pm 3.38$ & $48.88 \pm 3.38$ & $46.98 \pm 1.10$ \\
\hline
\end{tabular}

${ }^{a} p<0.05$ vs. yes inflamed $4 h$ no mix $4 h ;^{b} p<0.05$ vs. yes inflamed $4 h$ yes mix $4 h ;{ }^{c} p<0.05$ vs. yes inflamed $8 h$ no mix $8 h$. 

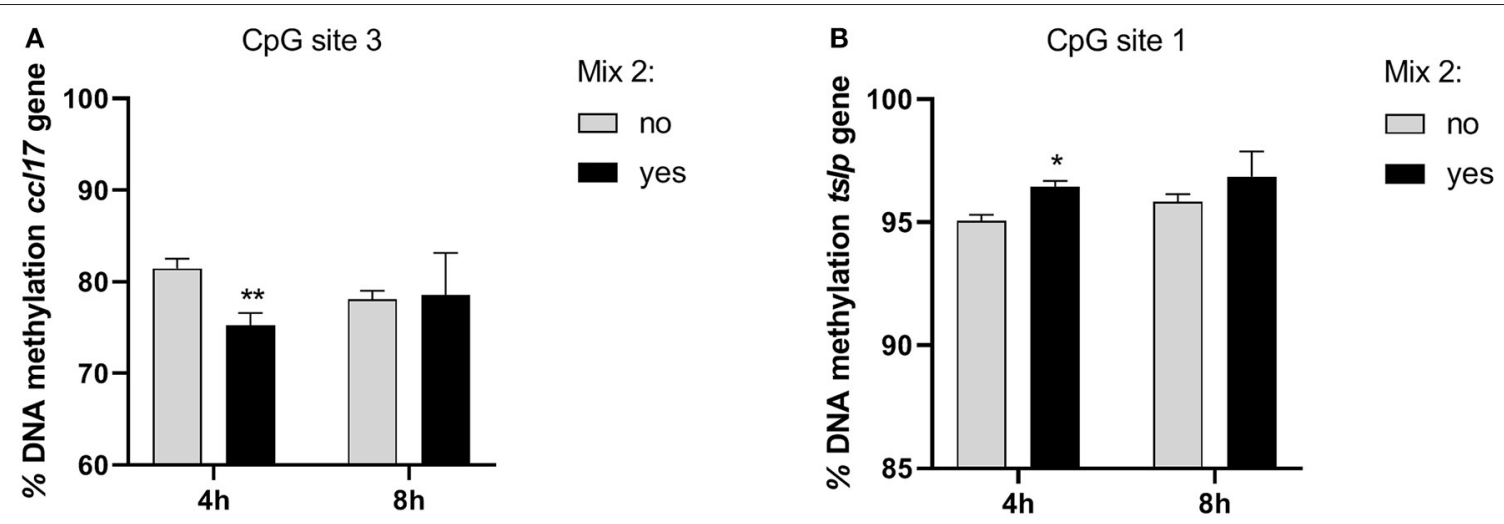

FIGURE 5 | The effects of the nutraceutical mixture on CpG island methylation in CPEK cells. Inflamed cells were treated (Mix yes) or not (Mix no) with the nutraceutical mixture (Mix 2) for 4 and $8 \mathrm{~h}$. The bar graphs represent the mean + SEM of three independent experiments performed in triplicate. The figure shows the methylation percentage with respect to $c c / 17$ (A) and ts/p (B) expressed as methylated cytosine/methylated cytosine + unmethylated cytosine. The statistically significant differences between experimental conditions are reported as follows: ${ }^{*} p<0.05,{ }^{* *} p<0.01$.

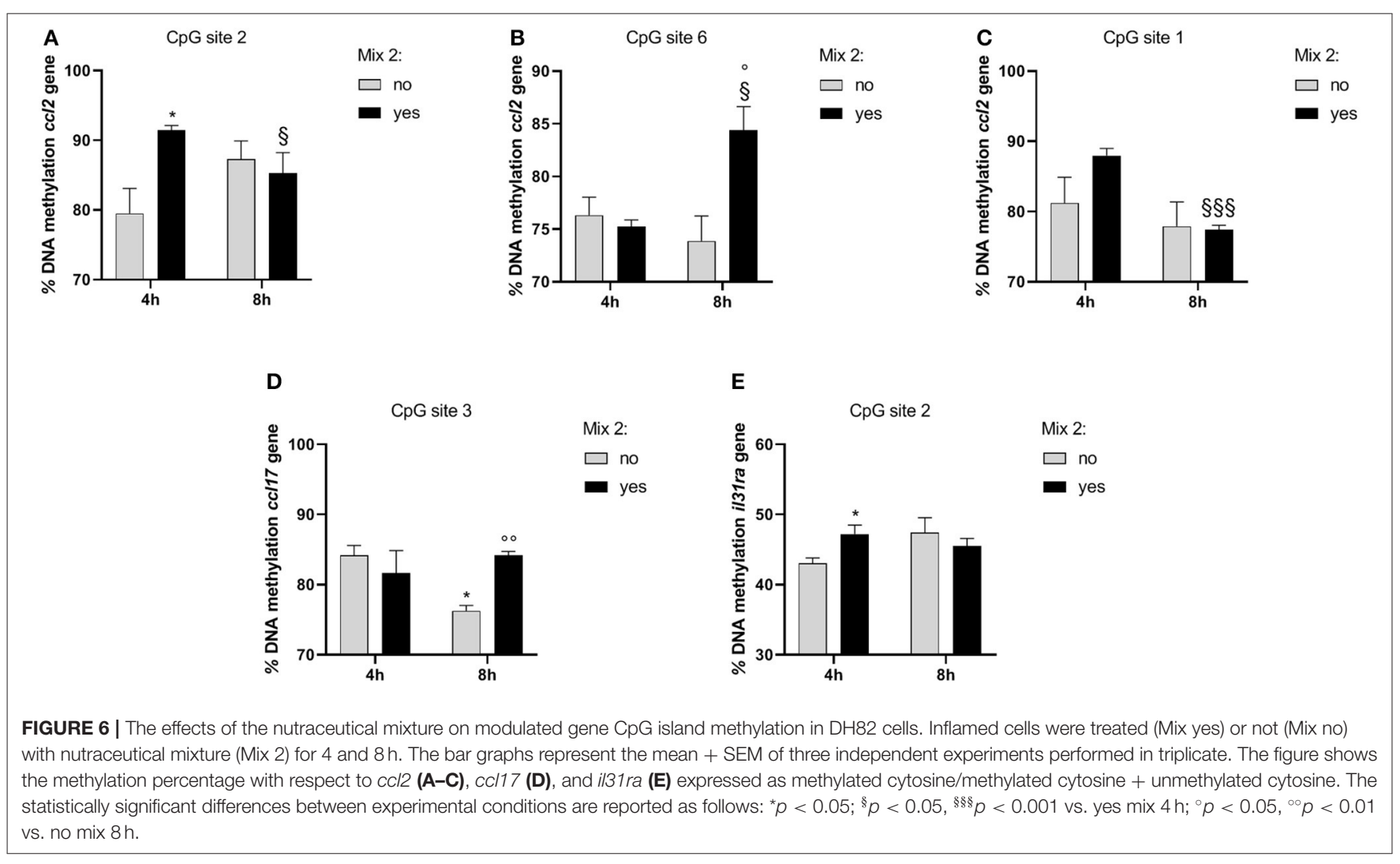

a Th1-mediated immune response $(17,35,36)$. In this work, the tested mixture containing luteolin, piceatannol, and cannabidiol interfered with the expression of marker genes associated with both Th1- and Th2-mediated inflammation. In particular, it reverted $c c l 2$ and $c c l 17$ overexpression in both tested cell lines and also downregulated tslp expression in CPEK cells and il31 ra expression in DH82 cells, as illustrated in Figure 7. The effects of the nutraceutical mixture were also evident with respect to $i l 4 r$ gene expression in CPEK cells and tslp gene expression in DH82 cells, but these effects were only time dependent. To the best of our knowledge, this is the first study in a canine in vitro model with a focus on the evaluation of epigenetic mechanisms at the basis of gene regulation evoked by the Th1/Th2 response and nutraceutical mixture treatment. CCL2 and CCL17 belong to a superfamily of secreted proteins involved in immunoregulatory and inflammatory processes driven by the Th1 and Th2 response, respectively (37). They are highly overexpressed in canine $\mathrm{AD}$ provoking leukocyte activation and 


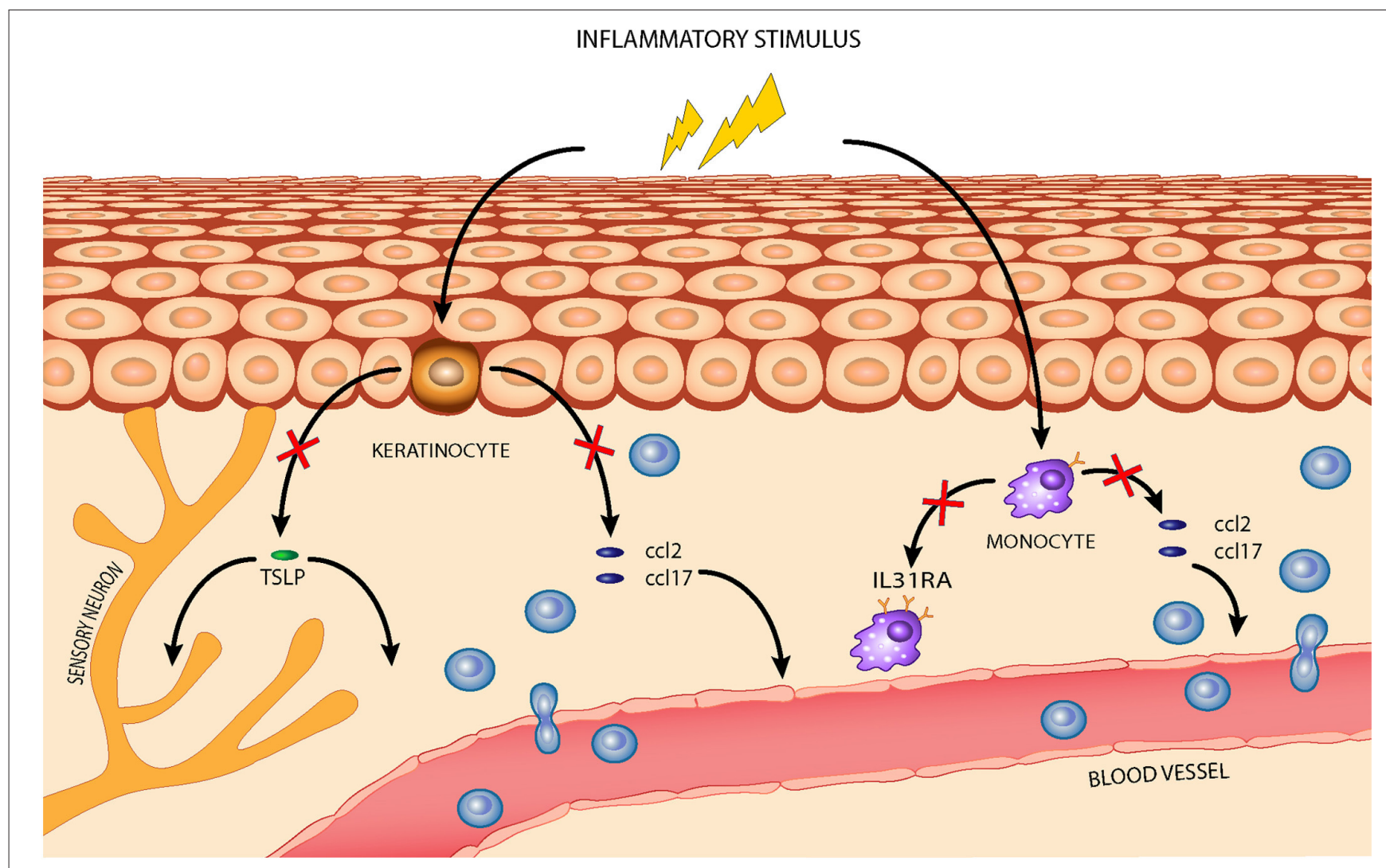

FIGURE 7 | The effects of the nutraceutical mixture in a canine AD model: the nutraceutical mixture (red cross) inhibited the overexpression of homing chemokines ccl2 and cc/17 in stimulated CPEK cells, reducing leukocyte infiltration from blood vessels, and of ts/p, reducing its activity in inflammatory cell recruitment and maturation. The nutraceuticals also decreased ccl2 and cc/17 expression in inflamed DH82 cells and downregulated il31ra expression, restraining Th2-mediated response amplification.

infiltration at the inflammatory sites in several pathologies (7). They represent new target molecules for AD therapy, together with TSLP, IL-4, and IL-31, that could dampen Th2 responses regulating the immune cell proliferation and stimulation of sensory cutaneous neurons to transmit itch sensation $(38,39)$.

The data in literature related to in vitro and in vivo effects of polyphenols and cannabidiol on Th1 homing cytokines support our results $(40,41)$. In this regard, $c c l 2$ expression was inhibited in human keratinocytes and skin treated with polyphenols in vitro and in vivo $(42,43)$; in murine monocyte cell lines, ccl2 blunting was observed after the luteolin treatment (44) and furthermore, piceatannol and cannabidiol are both capable of inhibiting $\mathrm{ccl} 2$ expression in activated macrophages in vitro $(45,46)$. The ability of polyphenols and cannabidiol to modulate Th2 response mediators $(47,48)$, including CCL17 and TSLP in AD models $(49,50)$, is equally well-known. Nutraceutical effects on both Th1/Th2 inflammatory mediators are uncommon, especially in dogs, whereas this represents a target for treating inflammatory stress and allergies in humans (51-53). The use of different active ingredients contained in food allows regulation of the different inflammation pathways involved in the chronic complex diseases. The mechanisms through which polyphenols and cannabidiol exert their gene modulatory functions are various and include epigenetic modifications $(54,55)$. The results show that the tested nutraceutical mixture affected the cell lines differently, even inhibiting the same genes. The $c c l 2$ promoter was strongly methylated in monocytes, for both exposure times and in different sites, while the mixture did not exert any effect on ccl2 promoter methylation in keratinocytes. In fact, our data agree with literature that $c c l 2$ gene promoter methylation is widely reported in human monocytes in vitro and in vivo, whereas no evidence can be found for the methylation of the ccl2 promoter in keratinocytes $(56,57)$. This can be explained by taking into account that the transcriptional regulation of $c c l 2$, in the context of non-resolving inflammation, appears to be more related to histone modification $(58,59)$. Methylation of the $c c l 17$ gene promoter affects both cell lines; an increase of ccl17 expression in vivo can be reverted with food supplements administration in patients with $\mathrm{AD}(56,57)$. In vitro, the transcriptional regulation of $c c l 17$ has been associated only with the transcriptional factor STAT6, which in turn plays a fundamental role in the activation of Th2 cells for ILs secretion (60). Of relevance, both animal and human studies suggest that functional nutrition can downregulate different proinflammatory transcriptional factors, including STAT6 (60). The association between $t s l p$ overexpression and $\mathrm{AD}$ onset has 
already been established in vivo, as well as its modulation through botanicals or probiotic supplementation $(61,62)$, Here, we demonstrated for the first time that the gene expression is ruled by epigenetic mechanisms; in fact, we observed an increase of the DNA methylation as a consequence of the nutraceutical mixture treatment. Likewise, literature reports less information on the transcriptional regulation of the il31ra gene despite its great relevance in $\mathrm{AD}$, especially with regard to therapeutic applications; indeed, IL-31RA has such a pivotal role in the AD pathogenesis that an anti-IL-31RA monoclonal antibody was developed as a novel strategy for targeting pruritus associated with AD (63). Finally, it has been observed that Th2 cells in situ are exposed to considerable changes in chromatin architecture and gene expression (64-66), suggesting a strong influence of the environment on their activation, and therefore, the possibility of intervention with nutritional supplements.

The health impact of natural substances depends on their pharmacokinetic features, particularly pertinent when these are administered by the oral route. Most ingredients from botanicals demonstrate very poor absorption features, and are extensively metabolized by intestinal and hepatic enzymes and interact, with often unpredictable effects, with the gut microbiota (67). Thus, not knowing the precise oral bioavailability of the active ingredients of the tested mixture could be a limitation of the study here. After oral administration of Chrysanthemum morifolium extract to rats at $1.7 \mathrm{~g} / \mathrm{kg}$ body weight, equivalent to 22.8 and $58.3 \mu \mathrm{mol} / \mathrm{kg}$ of luteolin and luteolin-7-O-glucoside, respectively, luteolin and its glycosides were quickly absorbed and luteolin, luteolin monoglucoside, and luteolin monoglucuronide were easily detected in the plasma with the highest levels of pure luteolin observed $1 \mathrm{~h}$ after oral administration, corresponding to $0.76 \pm 0.27 \mu \mathrm{M}$ (68). Although this result appears to be quite far from the dosage used here, the absorption rate of luteolin is known to be dose- and timedependent with plasma concentrations, increasing several-fold after repeated administration or higher doses, especially if it is coadministered with other ingredients (69). Moreover, the levels of absorbed luteolin, detected in plasma in the free form, can reach the values used in our work $(25 \mu \mathrm{M})$ by formulation with lipid carriers (70). With respect to piceatannol, the extent of its oral bioavailability characterizes this stilbene as also being an incompletely absorbed compound (71). In any case, in rats, the absolute oral bioavailability was as high as $50.7 \pm 15 \%$ of the administered dose (72). Regarding cannabidiol, this lipophilic phytocannabinoid is poorly water soluble and subjected to extensive first-pass metabolism in the gastrointestinal tract, leading to a limited oral bioavailability of $\sim 9 \%(73)$. However, natural substances, such as polyphenols, that can interfere with phase I and/or II enzymes and/or with enteric P-glycoprotein

\section{REFERENCES}

1. Brément T, Laly MJ, Combarros D, Guillemaille D, Bourdeau PJ, Bruet V. Reliability of different sets of criteria in diagnosing canine atopic dermatitis applied to a population of 250 dogs seen in a veterinary enhance its plasma levels in rats $\sim 6$-fold (73). Finally, among the three compounds tested in our investigation, cannabidiol is the only ingredient that has been studied in dogs, where its detected oral bioavailability ranged from 13 to $19 \%$ of the administered dose $(74,75)$. Therefore, despite our study being performed in vitro, these previously reported findings suggest that our results could be considered valid with respect to a nutraceutical approach to treating canine AD.

\section{CONCLUSION}

Considering the role of the Th1/Th2 inflammatory response in the pathomechanism of $\mathrm{AD}$, this canine model can be considered as an important development for the in vitro assessment of drugs and active ingredients. The tested nutraceutical mixture containing polyphenols and cannabinoids showed an ability to revert, through an epigenetic mechanism, the overexpression of canine AD key inflammatory genes, laying the groundwork for its application to sustained drug therapy or relapse prevention. The epigenetic modulation is involved in the induction, maintenance, heterogeneity, and recall response of memory $\mathrm{T}$ cells in Th1and Th2-related immunity (76), enabling the management of chronic inflammation through nutraceuticals that modulate DNA methylation.

\section{DATA AVAILABILITY STATEMENT}

The raw data supporting the conclusions of this article will be made available by the authors, without undue reservation.

\section{AUTHOR CONTRIBUTIONS}

MM, CD'A, and MP: conceptualization and writing, reviewing, and editing. MM: methodology. MM, EDV, and $\mathrm{BB}$ : investigation. $\mathrm{MM}$ and $\mathrm{MP}$ : formal analysis and writing (original draft preparation). FDP: visualization. $\mathrm{CR}$ and CD'A: supervision and project administration. All authors have contributed to and have approved the final manuscript.

\section{ACKNOWLEDGMENTS}

This investigation was supported by C.I.A.M. Srl.

\section{SUPPLEMENTARY MATERIAL}

The Supplementary Material for this article can be found online at: https://www.frontiersin.org/articles/10.3389/fvets. 2021.606197/full\#supplementary-material

teaching hospital. Vet Dermatol. (2019) 30:188-e59. doi: 10.1111/vde. 12729

2. Olivry T, DeBoer DJ, Favrot C, Jackson HA, Mueller RS, Nuttall T, et al. Treatment of canine atopic dermatitis: 2015 updated guidelines from the International Committee on Allergic Diseases of Animals 
(ICADA). BMC Vet Res. (2015) 11:210. doi: 10.1186/s12917-01 5-0514-6

3. Marsella R, Santoro D, Ahrens K, Thomas AL. Investigation of the effect of probiotic exposure on filaggrin expression in an experimental model of canine atopic dermatitis. Vet Dermatol. (2013) 24:260.e57. doi: 10.1111/vde. 12006

4. Colitti M, Stefanon B, Gabai G, Gelain ME, Bonsembiante F. Oxidative stress and nutraceuticals in the modulation of the immune function: current knowledge in animals of veterinary interest. Antioxidants. (2019) 8:28. doi: $10.3390 /$ antiox 8010028

5. Carlos-Reyes Á, López-González JS, Meneses-Flores M, GallardoRincón D, Ruíz-García E, Marchat LA, et al. Dietary compounds as epigenetic modulating agents in cancer. Front Genet. (2019) 10:79. doi: $10.3389 /$ fgene.2019.00079

6. Bin L, Leung DYM. Genetic and epigenetic studies of atopic dermatitis. Allergy, Asthma Clin Immunol. (2016) 12:52. doi: 10.1186/s13223-016-0158-5

7. Freudenberg JM, Olivry T, Mayhew DN, Rubenstein DS, Rajpal DK. The comparison of skin transcriptomes confirms canine atopic dermatitis is a natural homologue to the human disease. J Invest Dermatol. (2019) 139:96871. doi: $10.1016 /$ j.jid.2018.10.018

8. Plager DA, Torres SMF, Koch SN, Kita H. Gene transcription abnormalities in canine atopic dermatitis and related human eosinophilic allergic diseases. Vet Immunol Immunopathol. (2012) 149:136-42. doi: 10.1016/j.vetimm.2012.06.003

9. Schamber P, Schwab-Richards R, Bauersachs S, Mueller RS. Gene expression in the skin of dogs sensitized to the house dust mite Dermatophagoides farinae. G3. (2014) 4:1787-95. doi: 10.1534/g3.114.013003

10. Martel BC, Lovato P, Bäumer W, Olivry T. Translational animal models of atopic dermatitis for preclinical studies. Yale J Biol Med. (2017) 90:389-402.

11. Brunner PM, Guttman-Yassky E, Leung DYM. The immunology of atopic dermatitis and its reversibility with broad-spectrum and targeted therapies. J Allergy Clin Immunol. (2017) 139:S65-76. doi: 10.1016/j.jaci.2017. 01.011

12. Martins GDC, de Oliveira Melo Júnior OA, Botoni LS, Nogueira MM, da Costa Val AP, Blanco BS, et al. Clinical-pathological and immunological biomarkers in dogs with atopic dermatitis. Vet Immunol Immunopathol. (2018) 205:58-64. doi: 10.1016/j.vetimm.2018.10.009

13. Nuttall TJ, Knight PA, McAleese SM, Lamb JR, Hill PB. Expression of Th1, Th2 and immunosuppressive cytokine gene transcripts in canine atopic dermatitis. Clin Exp Allergy. (2002) 32:789-95. doi: $10.1046 / j .1365-2222.2002 .01356 . x$

14. Schlotter YM, Rutten VPMG, Riemers FM, Knol EF, Willemse T. Lesional skin in atopic dogs shows a mixed Type-1 and Type-2 immune responsiveness. Vet Immunol Immunopathol. (2011) 143:20-6. doi: 10.1016/j.vetimm.2011. 05.025

15. De Vuyst E, Salmon M, Evrard C, Lambert de Rouvroit C, Poumay Y. Atopic dermatitis studies through in vitro models. Front Med. (2017) 4:119. doi: 10.3389/fmed.2017.00119

16. Asahina R, Maeda S. A review of the roles of keratinocyte-derived cytokines and chemokines in the pathogenesis of atopic dermatitis in humans and dogs. Vet Dermatol. (2017) 28:16.e5. doi: 10.1111/vde.12351

17. Gonzales AJ, Bowman JW, Fici GJ, Zhang M, Mann DW, Mitton-Fry M. Oclacitinib (APOQUEL(B)) is a novel Janus kinase inhibitor with activity against cytokines involved in allergy. J Vet Pharmacol Ther. (2014) 37:317-24. doi: $10.1111 /$ jvp. 12101

18. Tanaka T, Iuchi A, Harada H, Hashimoto S. Potential beneficial effects of wine flavonoids on allergic diseases. Diseases. (2019) 7:8. doi: 10.3390/diseases 7010008

19. Robinson E, Murphy E, Friedman A. Knowledge, attitudes, and perceptions of cannabinoids in the dermatology community. J Drugs Dermatol. (2018) 17:1273-8.

20. Herrmann I, Gotovina J, Fazekas-Singer J, Fischer MB, Hufnagl K, Bianchini $\mathrm{R}$, et al. Canine macrophages can like human macrophages be in vitro activated toward the M2a subtype relevant in allergy. Dev Comp Immunol. (2018) 82:118-27. doi: 10.1016/j.dci.2018.01.005

21. Stott B, Lavender P, Lehmann S, Pennino D, Durham S, Schmidt-Weber CB. Human IL-31 is induced by IL-4 and promotes TH2-driven inflammation.
J Allergy Clin Immunol. (2013) 132:446-54.e5. doi: 10.1016/j.jaci.2013. 03.050

22. Petrosino $S$, Verde R, Vaia $M$, Allarà $M$, Iuvone $T$, Di Marzo V. Antiinflammatory properties of cannabidiol, a nonpsychotropic cannabinoid, in experimental allergic contact dermatitis. J Pharmacol Exp Ther. (2018) 365:652-63. doi: 10.1124/jpet.117.244368

23. Greiner G, Witzeneder N, Berger A, Schmetterer K, Eisenwort G, Schiefer A-I, et al. CCL2 is a KIT D816V-dependent modulator of the bone marrow microenvironment in systemic mastocytosis. Blood. (2017) 129:371-82. doi: 10.1182/blood-2016-09-739003

24. Weng Z, Patel AB, Vasiadi M, Therianou A, Theoharides TC. Luteolin inhibits human keratinocyte activation and decreases NF- $\mathrm{KB}$ induction that is increased in psoriatic skin. PLoS ONE. (2014) 9:e90739. doi: 10.1371/journal.pone.0090739

25. Jo BG, Park NJ, Jegal J, Choi S, Lee SW, Yi LW, et al. Stellera chamaejasme and its main compound luteolin 7- $\mathrm{O}$-glucoside alleviates skin lesions in oxazolone- and 2,4-dinitrochlorobenzene-stimulated murine models of atopic dermatitis. Planta Med. (2019) 85:583-90. doi: 10.1055/a-0746-8698

26. Sheriff $T$, Lin MJ, Dubin D, Khorasani H. The potential role of cannabinoids in dermatology. J Dermatol Treat. (2019) 31:839-45. doi: 10.1080/09546634.2019.1675854

27. Zhu T, Fang F, Sun D, Yang S, Zhang X, Yu X, et al. Piceatannol inhibits $P$. acnes-induced keratinocyte proliferation and migration by downregulating oxidative stress and the inflammatory response. Inflammation. (2019) 43:34757. doi: 10.1007/s10753-019-01125-8

28. Marchegiani A, Fruganti A, Spaterna A, Dalle Vedove E, Bachetti B, Massimini $\mathrm{M}$, et al. Impact of nutritional supplementation on canine dermatological disorders. Vet Sci. (2020) 7:38. doi: 10.3390/vetsci7020038

29. Yamazaki C, Rosenkrantz W, Griffin C. Pilot evaluation of Enterococcus faecium SF68 as adjunctive therapy for oclacitinib-responsive adult atopic dermatitis in dogs. J Small Anim Pract. (2019) 60:499-506. doi: 10.1111/jsap.13042

30. Anturaniemi J, Zaldívar-López S, Savelkoul HFJ, Elo K, HielmBjörkman A. The effect of atopic dermatitis and diet on the skin transcriptome in staffordshire bull terriers. Front Vet Sci. (2020) 7:552251. doi: 10.3389/fvets.2020.552251

31. Witzel-Rollins A, Murphy M, Becvarova I, Werre SR, Cadiergues MC, Meyer $\mathrm{H}$. Non-controlled, open-label clinical trial to assess the effectiveness of a dietetic food on pruritus and dermatologic scoring in atopic dogs. BMC Vet Res. (2019) 15:220. doi: 10.1186/s12917-019-1929-2

32. Gedon NKY, Mueller RS. Atopic dermatitis in cats and dogs: a difficult disease for animals and owners. Clin Transl Allergy. (2018) 8:41. doi: $10.1186 / \mathrm{s} 13601-018-0228-5$

33. de Roock S, van Elk M, van Dijk MEA, Timmerman HM, Rijkers GT, Prakken BJ, et al. Lactic acid bacteria differ in their ability to induce functional regulatory T cells in humans. Clin Exp Allergy. (2010) 40:103-10. doi: $10.1111 /$ j.1365-2222.2009.03344.x

34. Craig JM. Atopic dermatitis and the intestinal microbiota in humans and dogs. Vet Med Sci. (2016) 2:95-105. doi: 10.1002/vms3.24

35. Rodrigues MA, Torres T. JAK/STAT inhibitors for the treatment of atopic dermatitis. $J$ Dermatolog Treat. (2019) 31:33-40. doi: 10.1080/09546634.2019.1577549

36. Kieslinger M, Swoboda A, Kramer N, Pratscher B, Wolfesberger B, Burgener IA. Companion animals as models for inhibition of STAT3 and STAT5. Cancers. (2019) 11:2035. doi: 10.3390/cancers11122035

37. Hulshof L, Hack DP, Hasnoe QCJ, Dontje B, Jakasa I, Riethmüller C, et al. A minimally invasive tool to study immune response and skin barrier in children with atopic dermatitis. Br J Dermatol. (2019) 180:621-30. doi: $10.1111 /$ bjd. 16994

38. Storan ER, O'Gorman SM, McDonald ID, Steinhoff M. Role of cytokines and chemokines in itch. Handb Exp Pharmacol. (2015) 226:163-76. doi: 10.1007/978-3-662-44605-8_9

39. Klonowska J, Gleń J, Nowicki RJ, Trzeciak M. New cytokines in the pathogenesis of atopic dermatitis-new therapeutic targets. Int J Mol Sci. (2018) 19:3086. doi: 10.3390/ijms19103086

40. Joffre J, Yeh C-C, Wong E, Thete M, Xu F, Zlatanova I, et al. Activation of CB 1 R promotes lipopolysaccharide-induced IL-10 secretion by monocytic 
myeloid-derived suppressive cells and reduces acute inflammation and organ injury. J Immunol. (2020) 204:3339-50. doi: 10.4049/jimmunol.2000213

41. Yahfoufi N, Alsadi N, Jambi M, Matar C. The immunomodulatory and anti-inflammatory role of polyphenols. Nutrients. (2018) 10:1618. doi: $10.3390 /$ nu 10111618

42. Wedler J, Weston A, Rausenberger J, Butterweck V. In vitro modulation of inflammatory target gene expression by a polyphenol-enriched fraction of rose oil distillation waste water. Fitoterapia. (2016) 114:56-62. doi: 10.1016/j.fitote.2016.08.019

43. Carbone ML, Lulli D, Passarelli F, Pastore S. Topical plant polyphenols prevent type I interferon signaling in the skin and suppress contact hypersensitivity. Int J Mol Sci. (2018) 19:2652. doi: 10.3390/ijms19092652

44. Choi H-J, Choi H-J, Chung T-W, Ha K-T. Luteolin inhibits recruitment of monocytes and migration of Lewis lung carcinoma cells by suppressing chemokine (C-C motif) ligand 2 expression in tumorassociated macrophage. Biochem Biophys Res Commun. (2016) 470:101-6. doi: $10.1016 / j . b b r c .2016 .01 .002$

45. Eräsalo $H$, Hämäläinen $M$, Leppänen $T$, Mäki-Opas I, Laavola $M$, Haavikko $\mathrm{R}$, et al. Natural Stilbenoids Have Anti-inflammatory properties in vivo and down-regulate the production of inflammatory mediators NO, IL6, and MCP1 possibly in a PI3K/Akt-dependent manner. J Nat Prod. (2018) 81:1131-42. doi: 10.1021/acs.jnatprod.7b00384

46. Muthumalage T, Rahman I. Cannabidiol differentially regulates basal and LPS-induced inflammatory responses in macrophages, lung epithelial cells, and fibroblasts. Toxicol Appl Pharmacol. (2019) 382: 114713. doi: 10.1016/j.taap.2019.114713

47. Fan Y, Piao CH, Hyeon E, Jung SY, Eom J-E, Shin HS, et al. Gallic acid alleviates nasal inflammation via activation of Th1 and inhibition of Th2 and Th17 in a mouse model of allergic rhinitis. Int Immunopharmacol. (2019) 70:512-9. doi: 10.1016/j.intimp.2019.02.025

48. Gugliandolo E, Palma E, Cordaro M, D'Amico R, Peritore AF, Licata P, et al. Canine atopic dermatitis: role of luteolin as new natural treatment. Vet Med Sci. (2020) 6:926-32. doi: 10.1002/vms3.325

49. Jin SE, Ha H, Shin H-K, Seo C-S. Anti-allergic and anti-inflammatory effects of kuwanon $\mathrm{G}$ and morusin on MC/9 mast cells and HaCaT keratinocytes. Molecules. (2019) 24:265. doi: 10.3390/molecules24020265

50. Caglayan Sozmen S, Karaman M, Cilaker Micili S, Isik S, Arikan Ayyildiz Z, Bagriyanik A, et al. Resveratrol ameliorates 2,4-dinitrofluorobenzene-induced atopic dermatitis-like lesions through effects on the epithelium. PeerJ. (2016) 4:e1889. doi: 10.7717/peerj.1889

51. Rahimi K, Ahmadi A, Hassanzadeh K, Soleimani Z, Sathyapalan T, Mohammadi A, et al. Targeting the balance of $\mathrm{T}$ helper cell responses by curcumin in inflammatory and autoimmune states. Autoimmun Rev. (2019) 18:738-48. doi: 10.1016/j.autrev.2019.05.012

52. Sharma A, Joshi R, Kumar S, Sharma R, Rajneesh, Padwad Y, et al. Prunus cerasoides fruit extract ameliorates inflammatory stress by modulation of iNOS pathway and Th1/Th2 immune homeostasis in activated murine macrophages and lymphocytes. Inflammopharmacology. (2018) 26:1483-95. doi: 10.1007/s10787-018-0448-2

53. García-Martín A, Garrido-Rodríguez M, Navarrete C, Del Río C, Bellido ML, Appendino G, et al. EHP-101, an oral formulation of the cannabidiol aminoquinone VCE-004.8, alleviates bleomycininduced skin and lung fibrosis. Biochem Pharmacol. (2018) 157:304-13. doi: 10.1016/j.bcp.2018.07.047

54. Pucci M, Rapino C, Di Francesco A, Dainese E, D’Addario C, Maccarrone M. Epigenetic control of skin differentiation genes by phytocannabinoids. $\mathrm{Br} \mathrm{J}$ Pharmacol. (2013) 170:581-91. doi: 10.1111/bph.12309

55. Khan H, Sureda A, Belwal T, Çetinkaya S, Süntar I, Tejada S, et al. Polyphenols in the treatment of autoimmune diseases. Autoimmun Rev. (2019) 18:647-57. doi: 10.1016/j.autrev.2019.05.001

56. Gerrick KY, Gerrick ER, Gupta A, Wheelan SJ, Yegnasubramanian S, Jaffee EM. Transcriptional profiling identifies novel regulators of macrophage polarization. PLoS ONE. (2018) 13:e0208602. doi: 10.1371/journal.pone. 0208602

57. Yan DC, Hung CH, Sy LB, Lue KH, Shih IH, Yang CY, et al. A randomized, double-blind, placebo-controlled trial assessing the oral administration of a heat-treated lactobacillus paracasei supplement in infants with atopic dermatitis receiving topical corticosteroid therapy. Skin Pharmacol Physiol. (2019) 32:201-11. doi: 10.1159/000499436

58. Kiguchi N, Saika F, Kobayashi Y, Kishioka S. Epigenetic regulation of CCchemokine ligand 2 in nonresolving inflammation. Biomol Concepts. (2014) 5:265-73. doi: 10.1515/bmc-2014-0022

59. Cruickshank B, Giacomantonio M, Marcato P, McFarland S, Pol J, Gujar S. Dying to be noticed: epigenetic regulation of immunogenic cell death for cancer immunotherapy. Front Immunol. (2018) 9:654. doi: 10.3389/fimmu.2018.00654

60. Al Mijan M, Lim BO. Diets, functional foods, and nutraceuticals as alternative therapies for inflammatory bowel disease: present status and future trends. World J Gastroenterol. (2018) 24:2673-85. doi: 10.3748/wjg.v24.i25.2673

61. Kim HJ, Kim YJ, Lee SH, Yu J, Jeong SK, Hong SJ. Effects of Lactobacillus rhamnosus on allergic march model by suppressing Th2, Th17, and TSLP responses via CD4+CD25+Foxp3+ Tregs. Clin Immunol. (2014) 153:178-86. doi: 10.1016/j.clim.2014.04.008

62. Kim, SC. Fermented Morinda citrifolia (Noni) Alleviates DNCB-induced atopic dermatitis in NC/Nga mice through modulating immune balance and skin barrier function. Nutrients. (2020) 12:249. doi: 10.3390/nu12010249

63. Nakashima C, Otsuka A, Kabashima K. Interleukin-31 and interleukin-31 receptor: new therapeutic targets for atopic dermatitis. Exp Dermatol. (2018) 27:327-31. doi: 10.1111/exd.13533

64. Stark JM, Tibbitt CA, Coquet JM. The metabolic requirements of Th2 cell differentiation. Front Immunol. (2019) 10:2318. doi: 10.3389/fimmu.2019.02318

65. Buglio D, Georgakis GV, Hanabuchi S, Arima K, Khaskhely NM, Liu YJ, et al. Vorinostat inhibits STAT6-mediated TH2 cytokine and TARC production and induces cell death in Hodgkin lymphoma cell lines. Blood. (2008) 112:142433. doi: 10.1182/blood-2008-01-133769

66. Hsu AT, Lupancu TJ, Lee MC, Fleetwood AJ, Cook AD, Hamilton JA, et al. Epigenetic and transcriptional regulation of IL4-induced CCL17 production in human monocytes and murine macrophages. J Biol Chem. (2018) 293:11415-23. doi: 10.1074/jbc.RA118.002416

67. Manach C, Scalbert A, Morand C, Rémésy C, Jiménez L. Polyphenols: Food sources and bioavailability. Am J Clin Nutr. (2004) 79:727-47. doi: 10.1093/ajen/79.5.727

68. Yasuda MT, Fujita K, Hosoya T, Imai S, Shimoi K. Absorption and metabolism of luteolin and its glycosides from the extract of Chrysanthemum morifolium flowers in rats and Caco-2 cells. J Agric Food Chem. (2015) 63: 7693-9. doi: $10.1021 /$ acs.jafc.5b00232

69. Wang Y, Wang P, Xie J, Yin Z, Lin X, Zhao Y, et al. Pharmacokinetic comparisons of different combinations of yigan jiangzhi formula in rats: simultaneous determination of fourteen components by UPLC-MS/MS. $J$ Anal Methods Chem. (2020) 2020: 9353975. doi: 10.1155/2020/9353975

70. Liu Y, Wang L, Zhao Y, He M, Zhang X, Niu M, et al. Nanostructured lipid carriers versus microemulsions for delivery of the poorly water-soluble drug luteolin. Int J Pharm. (2014) 476:169-77. doi: 10.1016/j.ijpharm.2014.09.052

71. Roupe KA, Yáñez JA, Teng XW, Davies NM. Pharmacokinetics of selected stilbenes: rhapontigenin, piceatannol and pinosylvin in rats. J Pharm Pharmacol. (2006) 58:1443-50. doi: 10.1211/jpp.58.11.0004

72. Lin HS, Tringali C, Spatafora C, Wu C, Ho PC. A simple and sensitive HPLC-UV method for the quantification of piceatannol analog trans$3,5,3^{\prime}, 4^{\prime}$-tetramethoxystilbene in rat plasma and its application for a preclinical pharmacokinetic study. J Pharm Biomed Anal. (2010) 51:679-84. doi: 10.1016/j.jpba.2009.09.024

73. Cherniakov I, Izgelov D, Domb AJ, Hoffman A. The effect of Pro NanoLipospheres (PNL) formulation containing natural absorption enhancers on the oral bioavailability of delta-9-tetrahydrocannabinol (THC) and cannabidiol (CBD) in a rat model. Eur J Pharm Sci. (2017) 109:21-30. doi: 10.1016/j.ejps.2017.07.003

74. Samara E, Bialer M, Mechoulam R. Pharmacokinetics of cannabidiol in dogs. Drug Metab Dispos. (1988) 16:469-72.

75. Tufarelli V, Pero ME, Infascelli F, Della Rocca G, Di Salvo A. Hemp in veterinary medicine: from feed to drug. Front Vet Sci. (2020) 1:387. doi: $10.3389 /$ fvets. 2020.00387

76. Onodera A, Kokubo K, Nakayama T. Epigenetic and transcriptional regulation in the induction, maintenance, 
heterogeneity, and recall-response of effector and memory Th2 Cells. Front Immunol. (2018) 9:2929. doi: 10.3389/fimmu.2018. 02929

Conflict of Interest: The authors declare that this study received funding from C.I.A.M. Srl. The funder has the following involvement with the study: the writing of this article and the decision to submit it for publication.
Copyright $(2021$ Massimini, Dalle Vedove, Bachetti, Di Pierro, Ribecco, D’Addario and Pucci. This is an open-access article distributed under the terms of the Creative Commons Attribution License (CC BY). The use, distribution or reproduction in other forums is permitted, provided the original author(s) and the copyright owner(s) are credited and that the original publication in this journal is cited, in accordance with accepted academic practice. No use, distribution or reproduction is permitted which does not comply with these terms. 